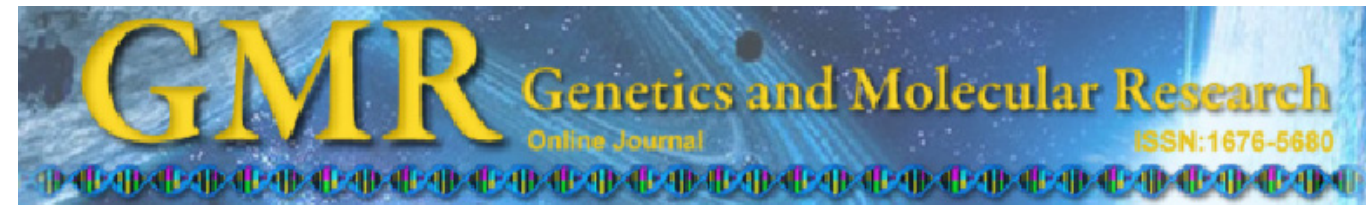

\title{
Leptin mRNA expression in the rat mammary gland at different activation stages
}

YY. Wang, Y.L. Wang, H.P. Li, H.S. Zhu, Q.D. Jiang, L. Zhang, L.F. Wang, L.Q. Han, K. Zhong, Y.J. Guo, W.F. Lu, H.J. Li and G.Y. Yang

Key Laboratory of Animal Biochemistry and Nutrition, Ministry of Agriculture, Henan Agricultural University, Zhengzhou, Henan, P.R. China

Corresponding author: G.Y. Yang

E-mail: wangyueying2008@126.com

Genet. Mol. Res. 10 (4): 3657-3663 (2011)

Received May 2, 2011

Accepted September 16, 2011

Published October 21, 2011

DOI http://dx.doi.org/10.4238/2011.October.21.3

ABSTRACT. Leptin is expressed in various tissues, suggesting that
this protein is effective not only at the central nervous system level,
but also peripherically. Recent studies have shown leptin production by
other tissues, including the placenta, stomach, and mammary tissues,
but there is no information available concerning expression levels of
leptin in the rat mammary gland at different activation stages. We used
semi-quantitative RT-PCR to investigate leptin mRNA expression levels
in the rat mammary gland at different activity stages. Rat mammary
gland samples were collected from virgin females and on days 6,12 ,
18 of pregnancy and of lactation (six rats per group). The expression
levels of leptin mRNA were measured by semi-quantitative RT-PCR,
with $\beta$-actin as an internal control. Leptin mRNA was highly expressed
in virgin rat mammary glands (leptin IOD $_{\text {I }} / \beta_{\text {-actin }}$ IOD $=1.60$ ). It decreased
gradually during pregnancy, being lowest at 18 days of pregnancy,
when the levels were significantly lower than in virgin mammary tissue.
Leptin mRNA increased slightly during lactation, but the difference
was not significant. By day 18 of lactation, expression levels of leptin
mRNA reached the same values as in virgin mammary tissue (leptin IOD $^{\prime}$ 
$\beta$-actin $\left.{ }_{\mathrm{IOD}}=1.65\right)$. Based on these results, we suggest that leptin has an important regulation role in rat mammary gland activation.

Key words: Leptin; Rat; Virgin; Pregnancy; Lactation

\section{INTRODUCTION}

Leptin is mainly, but not exclusively, an adipocyte-secreted protein (Zhang et al., 1994) that is involved in the regulation of food intake and energy balance (Houseknecht et al., 1998). Leptin has been implicated in numerous other roles, including modulation of reproduction, endocrine system, tissue metabolism, blood pressure, hematopoiesis, angiogenesis, brain and bone development, wound healing, and cell differentiation and proliferation (Ahima and Flier, 2000). Recently, there has been increasing evidence that it also acts as an autocrine and paracrine factor to influence development and lactation in the mammary gland. It promotes the development of ducts (Hu et al., 2002), formation of gland alveoli, expression of milk protein genes and onset of involution, which is necessary for the development and function of the mammary gland. However, the detection of leptin mRNA and (or) protein in human (SmithKirwin et al., 1998) and murine (Aoki et al., 1999) mammary tissue also suggests that leptin could be produced in the mammary gland. To date, research on leptin has been limited simply to mRNA expression of leptin (Aoki et al., 1999) and the impact of leptin on proliferation and differentiation of mammary epithelial cells (Baratta et al., 2003). There has been no systematic research about leptin expression levels in the rat mammary gland in pregnancy and lactation. In order to determine the expression of leptin mRNA in the whole developmental cycle of the mammary gland, and to elucidate the impact and mechanism of leptin in the mammary gland in pregnancy and lactation, rats were used to investigate the expression of leptin mRNA in the whole developmental cycle by semi-quantitative reverse transcription polymerase chain reaction (RT-PCR).

\section{MATERIAL AND METHODS}

\section{Animals and treatment}

Six-week-old Sprague-Dawley rats were obtained from the Centre for Laboratory Animals of Henan Province. Animals were maintained in group cages under controlled conditions of temperature $\left(25^{\circ} \pm 1^{\circ} \mathrm{C}\right)$ and light (L:D, 12:12), with ad libitum access to food and water. At 8 weeks, females were either mated or culled for virgin mammary glands. Pregnant animals were monitored daily to define day of lactation. At postpartum, a minimum of six pups per suckling female were ensured by cross-fostering where appropriate. Lactating mammary glands were monitored daily for signs of localized inflammation or mastitis. All procedures were approved by the Animal Ethics Committee.

\section{Harvesting mammary gland}

A total of 7 stages of adult rat mammary gland development were selected for this study: 8-week-old virgin; 6,12 and 18 days of gestation (in which day 1 was the first day 
postcoitum); and 6,12 and 18 days of lactation (in which day 1 was the second day postpartum). All mammary glands were harvested between 11:00 and 13:00 to limit circadian effects. A total of six animals were used per time point. In each case, a single abdominal gland was removed following excision of lymph nodes and immediately frozen in liquid nitrogen.

\section{RNA extraction and reverse transcription}

Total RNA was extracted from rat mammary gland with the TRIzol reagent kit (Invitrogen Inc., Carlsbad, USA) and used for the determination of leptin messenger RNA (mRNA) by RT-PCR. All extracted RNA samples were finally dissolved in RNase-free water. The purity of the dissolved RNA was assessed by the A260nm/A280nm ratio measured using a UV/visible spectrophotometer (Nanodrop 2000/2000C; Thermo Scientific, Wilmington, USA). The integrity of RNA was determined by denaturing agarose gelelectrophoresis. Total RNA was extracted following a conventional protocol and was dissolved with $20 \mu \mathrm{L}$ RNase-free water.

RNA was reverse transcribed with a reaction mix containing $6.5 \mu \mathrm{L}$ DEPC- $\mathrm{H}_{2} \mathrm{O}, 4 \mu \mathrm{L}$ $5 \mathrm{X}$ buffer, $4 \mu \mathrm{L} 2.5 \mathrm{mM}$ dNTP mix, $1 \mu \mathrm{L} 50 \mathrm{pM}$ Oligo(dT)18, $2 \mu \mathrm{L} 5 \mathrm{U} / \mu \mathrm{L}$ AMV, $0.5 \mu \mathrm{L} 40 \mathrm{U} /$ $\mu \mathrm{L}$ RNase inhibitor, $2 \mu \mathrm{L}$ RNA. The total reaction volume was $20 \mu \mathrm{L}$. After gently mixing, the solution was incubated for $60 \mathrm{~min}$ at $42^{\circ} \mathrm{C}$, and then for $15 \mathrm{~min}$ at $72^{\circ} \mathrm{C}$, followed by $2 \mathrm{~min}$ in an ice bath. Two controls were done in the RT reaction, one control was prepared using all reagents except the RNA sample, for which an equivalent volume of water was substituted, and the other control was prepared using all reagents except reverse transcriptase. The controls underwent identical PCR procedures as experimental samples. The cDNA product was stored at $-20^{\circ} \mathrm{C}$.

\section{RT-PCR}

The primers used for amplification of leptin mRNAs were determined using the Primer Premier TM Version 5.0 software (PREMIER Biosoft International, Canada) and checked by BLAST searches. All of the primers, including those for the $\beta$-actin gene as an internal reference, were synthesized by Shanghai Sango Biological Engineering Technology \& Services Co. Ltd. (China). Electrophoresis in $1.2 \%(\mathrm{w} / \mathrm{v})$ agarose gels was conducted to determine the quality and integrity of the primers. Sequence of primers and product size were as follows: leptin, sense 5'-tggtcctatctg tcctatgtt-3', antisense 5'-ggaggtctcgcaggttct-3', product $286 \mathrm{bp} ; \beta$-actin, sense 5'-ctccetatggetccttcatgc-3', antisense 5'-ccettctggtgctgctgctt-3', product $520 \mathrm{bp}$.

The cDNAs obtained were further amplified by PCR in a $25-\mu \mathrm{L}$ mix consisting of 1 $\mu \mathrm{L}$ RT reaction solution, $12.5 \mu \mathrm{L} 2 \mathrm{X}$ Master mix, $1 \mu \mathrm{L} 20 \mathrm{pM}$ forward primer, $1 \mu \mathrm{L} 20 \mathrm{pM}$ reverse primer, and $9.5 \mu \mathrm{L}$ sterilized $\mathrm{H}_{2} \mathrm{O}$. The reaction substrates were mixed by gently flicking the bottom of each tube. PCR amplification was carried out for 35 cycles $\left(95^{\circ} \mathrm{C}, 10 \mathrm{~s} ; 53^{\circ} \mathrm{C}, 20\right.$ $\left.\mathrm{s} ; 72^{\circ} \mathrm{C}, 30 \mathrm{~s}\right)$ for $\beta$-actin and 35 cycles $\left(95^{\circ} \mathrm{C}, 10 \mathrm{~s} ; 52^{\circ} \mathrm{C}, 20 \mathrm{~s} ; 72^{\circ} \mathrm{C}, 30 \mathrm{~s}\right)$ for leptin. Reactions were completed with a final extension at $72^{\circ} \mathrm{C}$ for $10 \mathrm{~min}$. For each $5-\mu \mathrm{L}$ sample, PCR amplification products were mixed gently with $3 \mu \mathrm{L}$ fluorochrome before protection from light for $10 \mathrm{~min}$, and then visualized on $1.2 \%$ agarose gel with MultiImage Light system.

\section{Statistical treatment of results}

All results were expressed as mean \pm SD and analyzed by the Statistical Package for 
the Social Sciences (SPSS) statistical software (version 13.0). Differences between group data were analyzed using the Student-Newman-Keuls post hoc test of one-way analysis of variance (ANOVA), and differences between groups were evaluated using the paired-samples $t$ test. Significance was set at $\mathrm{P}<0.05$ and $\mathrm{P}<0.01$ in two-tailed testing.

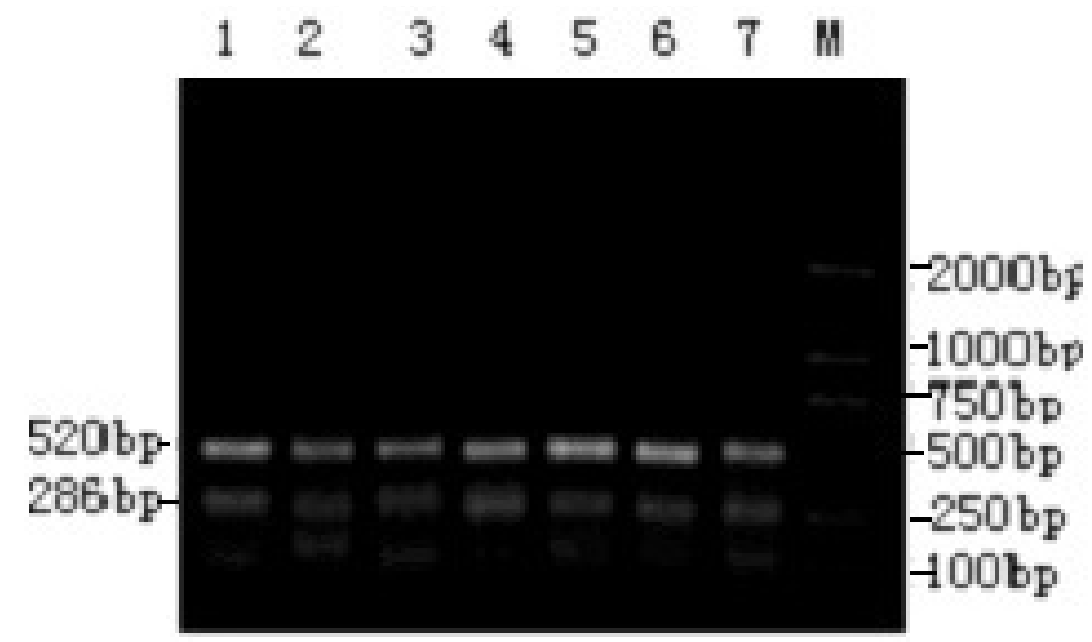

Figure 1. Gel electrophoresis of RT-PCR products in rat mammary gland, Lane $M=$ Marker; lane $1=$ Virgin; lane $2=\mathrm{P}-6 \mathrm{~d}$; lane $3=\mathrm{P}-12 \mathrm{~d}$; lane $4=\mathrm{P}-18 \mathrm{~d}$; lane $5=\mathrm{L}-6 \mathrm{~d}$; lane $6=\mathrm{L}-12 \mathrm{~d}$; lane $7=\mathrm{L}-18 \mathrm{~d}$.

\section{RESULTS}

Gel electrophoresis showing RT-PCR of leptin in rat mammary gland indicated that a single PCR product of about 286 bp was obtained in all samples (Figure 1). The relative expression level of leptin mRNA in rat mammary gland during virgin condition, pregnancy and lactation were shown in Table 1 and Figure 2.

Leptin mRNA was highly expressed in virgin rat mammary gland (1.60), then decreased gradually during pregnancy, where it was lowest on $\mathrm{P} 18(1.20, \mathrm{P}<0.05)$. Leptin mRNA levels during lactation increased slightly compared to those during pregnancy, but difference were not significant $(\mathrm{P}>0.05)$. Expression level of leptin mRNA on L18 (1.65) was the same value as that of virgin.

Table 1. Expression level of leptin mRNA relative to $\beta$-actin in mammary gland during pregnancy and lactation.

\begin{tabular}{lcc}
\hline Group & Number of samples & Leptin/ $\beta$-actin $($ IOD) \\
\hline Virgin & 6 & $1.60 \pm 0.21^{\mathrm{b}}$ \\
P-6d & 6 & $1.52 \pm 0.34^{\mathrm{ab}}$ \\
P-12d & 6 & $1.39 \pm 0.54^{\mathrm{ab}}$ \\
P-18d & 6 & $1.20 \pm 0.11^{\mathrm{a}}$ \\
L-6 d & 6 & $1.25 \pm 0.27^{\mathrm{a}}$ \\
L-12 d & 6 & $1.40 \pm 0.13^{\mathrm{ab}}$ \\
L-18 d & 6 & $1.65 \pm 0.31^{\mathrm{b}}$ \\
\hline
\end{tabular}

IOD = integrated optical density. 


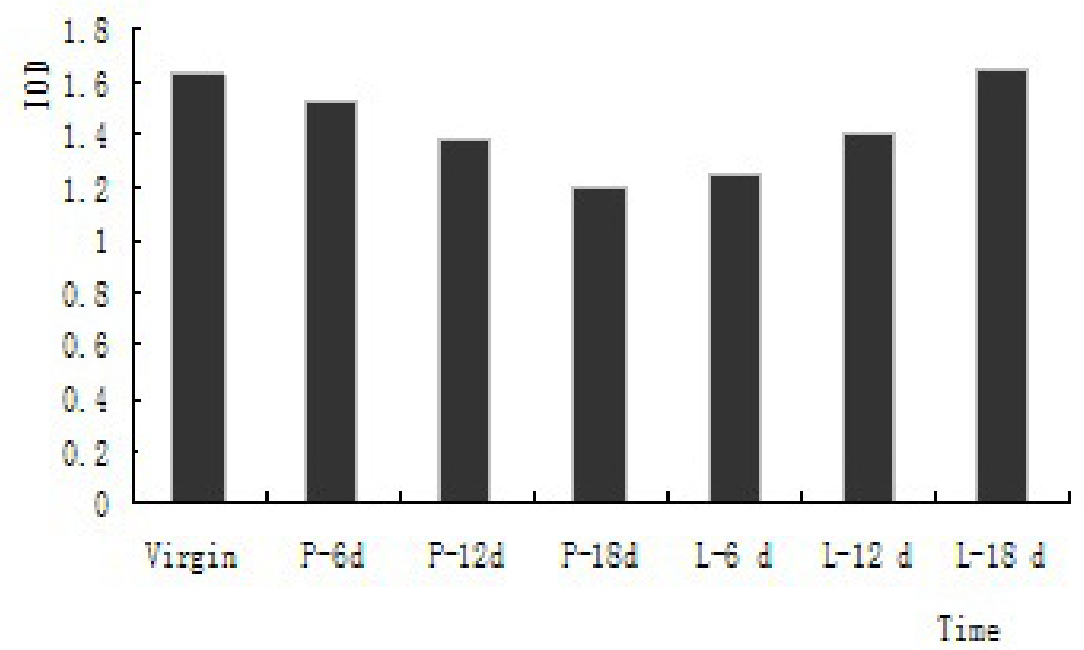

Figure 2. Expression levels of leptin mRNA relative to $\beta$-actin in rat mammary gland at different developmental stages.

\section{DISCUSSION}

The adipocyte-derived hormone leptin is an essential mediator of energy homeostasis in mice and humans (Hu et al., 2002). Although the initial studies implicating leptin in human obesity are controversial, recent genetic studies clearly demonstrate that even a modest decrease in functional leptin levels is compensated by an increase in fat mass in humans (Farooqi et al., 2001).

Adipose tissue, however, is not the only tissue that expresses leptin. Leptin can be expressed in both normal and malignant breast tissues (Smith-Kirwin et al., 1998; O'Brien et al., 1999). Whether leptin is involved in the regulation of normal mammary gland development has not been examined extensively. The expression of leptin has been described, however, in normal human mammary tissues (Smith-Kirwin et al., 1998; O'Brien et al., 1999) and in human breast tumor cell lines and breast tumors (O'Brien et al., 1999). Studies demonstrate that leptin can stimulate the proliferation of both normal and malignant breast epithelial cells by activating the leptin receptor (Hu et al., 2002). These findings suggest that both leptin and an intact leptin-signaling pathway are necessary for normal mammary gland development.

Plasma leptin levels are increased during pregnancy in the rat (Amico et al., 1998) and humans (Butte et al., 1999), as expected from the increase in adipose tissue observed at this stage. Plasma leptin levels were decreased in lactating rats possibly contributing to the hyperphagia of lactation (Woodside et al., 2000). Lin and Li (2007) found that the expression of leptin was highest in virgin animals, and then decreased in pregnancy. Leptin expression remained the lowest during the whole lactation period. From $12 \mathrm{~d}$ lactation, the expression of leptin was significantly upregulated and recovered to the original virgin level on involution (13 d).

We also found that leptin mRNA was highly expressed in virgin rat mammary gland (1.60), then decreased gradually during pregnancy, where it was lowest on P18 $(1.20, \mathrm{P}<$ 
0.05). Leptin mRNA during lactation increased slightly compared to that during pregnancy, but differences were not significant $(\mathrm{P}>0.05)$. Expression level of leptin mRNA on L18 (1.65) was the same as that of virgin. Leptin is mainly synthesized and secreted by adipocytes. Therefore, the amount of leptin in mammary gland depends on the protein secreted by fat tissues. In virgin tissue, there is little parenchyma and most areas in the mouse mammary gland are occupied by a fat pad. In this period, the expression of leptin was shown to be the highest. In pregnancy, estrogen and progesterone induce the branching of mammary ducts. With the regression of mammary fat pads, the expression of leptin decreases (Lin and Li, 2007). This coincides with the finding that in mice with decreasing mammary leptin mRNA level around the first third of pregnancy, mammary adipocyte numbers are markedly reduced (Elias et al., 1973). Contrary to the impact of prolactin on leptin expression in cow mammary gland during lactation (Feuermann et al., 2004), prolactin inhibited the expression of leptin in mouse mammary gland (Aoki et al., 1999). During lactation, prolactin is high, so the expression of leptin is kept low.

Bonnet et al. (2002) reported the first evidence that ovine mammary tissue expresses leptin mRNA during lactation. This result is in agreement with the mammary synthesis of leptin previously reported in humans (Smith-Kirwin et al., 1998) and mice (Aoki et al., 1999). Bonnet also reported strong variations in ovine mammary leptin gene expression depending on the stage of pregnancy or lactation. Leptin mRNA was expressed throughout pregnancy, with a marked decrease in expression at mid-pregnancy. During lactation, the leptin mRNA levels were lower than or similar to those observed at the end of pregnancy. Indeed, their results suggest an increased synthesis of leptin by mammary adipocytes at the beginning of pregnancy that decreases to a lower level during the second part of pregnancy when adipocytes disappear. These sequential changes suggest that leptin could act as a paracrine factor in mammary gland growth, development, and function. This would help us to better understand the mechanisms for the known effect of nutritional factors and body fat on peripubertal mammogenesis. Our results suggest that leptin has an important regulatory role in the development of the rat mammary gland.

\section{ACKNOWLEDGMENTS}

(\#2011CB100802).

\section{REFERENCES}

Ahima RS and Flier JS (2000). Adipose tissue as an endocrine organ. Trends Endocrinol. Metab. 11: 327-332.

Amico JA, Thomas A, Crowley RS and Burmeister LA (1998). Concentrations of leptin in the serum of pregnant, lactating, and cycling rats and of leptin messenger ribonucleic acid in rat placental tissue. Life Sci. 63: 1387-1395.

Aoki N, Kawamura M and Matsuda T (1999). Lactation-dependent down regulation of leptin production in mouse mammary gland. Biochim. Biophys. Acta 1427: 298-306.

Baratta M, Grolli S and Tamanini C (2003). Effect of leptin in proliferating and differentiated HC11 mouse mammary cells. Regul. Pept. 113: 101-107.

Bartha T, Sayed-Ahmed A and Rudas P (2005). Expression of leptin and its receptors in various tissues of ruminants. Domest. Anim. Endocrinol. 29: 193-202.

Bonnet M, Gourdou I, Leroux C, Chilliard Y, et al. (2002). Leptin expression in the ovine mammary gland: putative sequential involvement of adipose, epithelial, and myoepithelial cells during pregnancy and lactation. J. Anim. Sci. 
80: 723-728.

Butte NF, Hopkinson JM, Mehta N, Moon JK, et al. (1999). Adjustments in energy expenditure and substrate utilization during late pregnancy and lactation. Am. J. Clin. Nutr. 69: 299-307.

Clevenger CV and Plank TL (1997). Prolactin as an autocrine/paracrine factor in breast tissue. J. Mammary Gland. Biol. Neoplasia 2: 59-68.

Elias JJ, Pitelka DR and Armstrong RC (1973). Changes in fat cell morphology during lactation in the mouse. Anat. Rec. 177: 533-547.

Farooqi IS, Keogh JM, Kamath S, Jones S, et al. (2001). Partial leptin deficiency and human adiposity. Nature 414: 34-35.

Feuermann Y, Mabjeesh SJ and Shamay A (2004). Leptin affects prolactin action on milk protein and fat synthesis in the bovine mammary gland. J. Dairy Sci. 87: 2941-2946.

Houseknecht KL, Baile CA, Matteri RL and Spurlock ME (1998). The biology of leptin: a review. J. Anim. Sci. 76: 14051420.

Hu X, Juneja SC, Maihle NJ and Cleary MP (2002). Leptin - a growth factor in normal and malignant breast cells and for normal mammary gland development. J. Natl. Cancer Inst. 94: 1704-1711.

Jin LL, Zhang S, Burguera BG, Couce ME, et al. (2000). Leptin and leptin receptor expression in rat and mouse pituitary cells. Endocrinology 141: 333-339.

Lin Y and Li Q (2007). Expression and function of leptin and its receptor in mouse mammary gland. Sci. China C Life Sci. 50: 669-675.

Malik NM, Carter ND, Murray JF, Scaramuzzi RJ, et al. (2001). Leptin requirement for conception, implantation, and gestation in the mouse. Endocrinology 142: 5198-5202.

Mol JA, Lantinga-van L, I, van Garderen E and Rijnberk A (2000). Progestin-induced mammary growth hormone (GH) production. Adv. Exp. Med. Biol. 480: 71-76.

Neville MC, McFadden TB and Forsyth I (2002). Hormonal regulation of mammary differentiation and milk secretion. $J$. Mammary Gland. Biol. Neoplasia 7: 49-66.

O'Brien SN, Welter BH and Price TM (1999). Presence of leptin in breast cell lines and breast tumors. Biochem. Biophys. Res. Commun. 259: 695-698.

Sayed-Ahmed A, Kulcsar M, Rudas P and Bartha T (2004). Expression and localisation of leptin and leptin receptor in the mammary gland of the dry and lactating non-pregnant cow. Acta Vet. Hung. 52: 97-111.

Smith-Kirwin SM, O’Connor DM, De JJ, Lancey ED, et al. (1998). Leptin expression in human mammary epithelial cells and breast milk. J. Clin. Endocrinol. Metab. 83: 1810-1813.

Smith JL and Sheffield LG (2002). Production and regulation of leptin in bovine mammary epithelial cells. Domest. Anim. Endocrinol. 22: 145-154.

Woodside B, Abizaid A and Walker C (2000). Changes in leptin levels during lactation: implications for lactational hyperphagia and anovulation. Horm. Behav. 37: 353-365.

Zhang Y, Proenca R, Maffei M, Barone M, et al. (1994). Positional cloning of the mouse obese gene and its human homologue. Nature 372: 425-432. 